\author{
Дзюба Т. А., \\ доктор наук із соціальних комунікацій, \\ професор кафедри філологічних \\ дисциплін та методики їх викладання \\ Чернігівського обласного інституту \\ післядипломної педагогічної освіти \\ імені К. Д. Ушинського
}

\title{
ВІЗІЯ ПЕРШОЇ СВІТОВОЇ ВІЙНИ У ПРОЗІ ЙОЗЕФА РОТА: ЧАСОПРОСТІР, ІДЕНТИЧНІСТЬ, КАТАСТРОФІЗМ
}

У пропонованому дослідженні проаналізовано тексти відомого австрійського прозаїка Йозефа Рота (1894-1939) про Першу світову війну в їі екзистенційних вимірах. Головним мотивом художнього та публічистичного універсуму автора є мотив руйнування старого світу - розпад Австро-Угорської імперії, занапащення сформованої системи культурних орієнтирів, випробування індивіда історією та долею. В епоху історичних катаклізмів переформатовується часопростір, зокрема, в героїв Й. Рота виникає бажання жити минулим, 3'являється туга за втраченим «золотим віком», а фактично - міфом монархї. Відтворена письменником широка сочіальна панорама дає змогу простежити пошуки нової ідентичності представниками різних сочіальних груп.

Ключові слова: «втрачене покоління», мотив, екзистенційна категорія, міфокомплекс, хронотоп.

В предлагаемом исследовании проанализировань тексты известного австрийского прозаика Йозефа Рота (1894-1939) о Первой мировой войне в ее экзистенциальных измерениях. Основным мотивом художественного и публицистического универсума автора предстаёт мотив гибели старого мира - распад Австро-Венгрии, утрата сложивщейся системы культурных ориентиров, испьтание человека историей и судьбой. $B$ эпоху исторических катаклизмов переформатируется пространство, смещается время, 6 частности, героям Й. Рота присуще желание жить прошлым, у них появляется тоска по утраченному "золотому веку» - Австро-Венгерской монархии, тоска по мифу. Широкая сочиальная панорама, созданная писателем, позволяет изучить поиски представителями различных общественных групп новой идентичности.

Ключевые слова: «потерянное поколение», мотив, экзистенциальная категория, мифо-комплекс, хронотоп.

The study analyzed the prose of the famous Austrian writer, Joseph Roth (1894-1939), dedicated to the First World War in its existential dimensions. The leitmotif of the author's artistic and journalistic universe is the destruction of the old world, the collapse of the Austro-Hungarian Empire, the decay of the existing system of cultural references, and the impact of history and fate on the individual. The era of historical cataclysms reformats time and space. In particular, Roth's characters want to live in the past; they have nostalgia for the lost "golden age», which, in fact, is a myth of monarchy. The broad social panorama created by the writer let the reader track a new identity searched for by members of different social groups.

Key words: lost generation, motif, existential category, myth-complex, time and space.

\section{Як безпосередньому учаснику й свідку тодішніх подій, автору} притаманне загострене образно-художнє відтворення воєнних реалій. Романи, повісті, новели літератора містять колаж із дійсних та вигаданих історій. 
Актуальність дослідження зумовлена, зокрема, i розширенням діапазону перекладених українською мовою творів Йозефа Рота; збагаченням контексту (а ним $є$ література багатонаціональної Австро-Угорщини часів Франца Йосифа II та після розпаду імперії), введенням до наукового вжитку низки грунтовних праць зарубіжних та вітчизняних науковців. Таких, як дослідження автобіографії Й. Рота (Д. Бронзен, США; Г. Ньюрнбергер, Німеччина), матеріали міжнародного симпозіуму «Joseph Roth: Interpretation, Kritik, Rezeption» (1990); публікація в перекладі російською мовою листування письменника [Рот 1994:174-227], видання творів Йозефа Рота у 6-ти томах (Кельн, 1989-1991), перевидання публіцистики Й. Рота «Reise nach Russland» (Кельн, 1995), переклад розвідки «Il mito absburgico nella letteratura austriaca moderna» італійського германіста Клаудіо Магріса, одного 3 перших i найгрунтовніших дослідників «габсбурзького міфу», студії С. Розенфельда, С. Кіфера. Нами також враховані написані в різний час праці російських літературознавців: Ю. Архипова, Л. Безірової, А. Бєлобратова, Н. Веселовської, Л. Єфремової, А. Кацури, В. Проніна, В. Сєдєльніка та ін.; дослідження українських вчених: Т. Гавриліва, Т. Дзися, Д. Затонського, М. Зимомрі, Г. Петросаняк, П. Рихла, Л. Цибенко.

У нашій розвідці простежена трансформація хронотопу воєнного світу, розглянутий феномен «втраченого покоління». У повісті «Втеча без кінця» це поняття концептуалізується у заключному вислові: «Таким зайвим, як він, у цุьому світі не був ніхто» [Roth 1984:Електронний ресурс]. Виміри хронотопу в художній площині співвідносяться 3 періодом Першої світової війни (19141918) та повоєнними роками і охоплюють етапи: порушення гармонійного перетікання часу (моделювання початку світової війни), вир Першої світової (роман «Марш Радецького», повість «Начальник станції Фальмерайєр», у яких відтворена модель людини на війні та наскрізні, архетипного рівня концепти); стадію після формального завершення війни (повісті «Готель «Савой», «Втеча без кінця»). 
Спосіб існування індивіда на війні (різних категорій людей) створюється на основі біографічно-хронологічних параметрів самого Йозефа Рота як автора, геополітичних, культурно-історичних характеристик, світоглядно-естетичних дискурсів і поетикально-наративних домінант. Катастрофізм буття дійсних. а згодом колишніх учасників воєнних подій, переданий через мотиви поневірянь, злигоднів, полону, «втечі без кінця», пошуку коштів для виживання, втрати дому, рідних, країни, місця в житті, передчуття нових, ще масштабніших потрясінь. Модель війни у прозі Йозефа Рота окреслюється шляхом уведення таких екзистенційних категорій, як: любов, співчуття, страждання, покута, хвороба, смерть тощо.

У прозі письменника («Втеча без кінця», «Готель ”Савойе»), «Марш Радецького», «Фальшива вага. Історія одного айхмістра», «Тріумф краси», «Погруддя цісаря», «Йов») наявна широка репрезентація австрійсько-галицької людності, укладений «реєстр» характерних персонажів - типажів. Це Карл Йозеф Тротта, його денщик Онуфрій, Ансельм Айбеншютц, Габріель Дан, Франц Ксавер Морштин, Вошивко Печеник, доктор Сковронек, пані Гвенделін, адвокат Лакотош, учитель Мендель Зінгер 3 дружиною Деборою, сини Менухім, Шемара і дочка Мір'ям, писар-спекулянт Каптурак. Усі вони представники «збірного топосу», ареалу «габсбурзького міфу». Багатоетнічне середовище пов'язується з проблемою самоідентифікації не лише героїв, але й самого автора. За спостереженням Стефана Цвейга, яке він висловив у відомому есеї, написаному на смерть товариша, Йозеф Рот поєднував у собі щонайменше три натури (ідентичності): єврейську, австрійську, російську [Цвейг 2003: Електронний ресурс]. Хоча у дійсності їх було більше, наведений перелік доповнювався, зокрема українськими та польськими акцентами. Щоправда, у власних публіцистичних творах Йозеф Рот декларував своєрідний космополітизм, виходячи поза межі етнічного виміру. На думку А. Красільщікова [Красильщиков 2013: Електронний ресурс], у такий спосіб, окрім іншого, він уникав родового єврейства. 
У художніх текстах Йозефа Рота досвід війни розглянутий і крізь призму гендерної проблематики. Зокрема, у «Начальникові станції Фальмерайєрові» аспект: жінка на тлі війни увиразнюється на прикладі життєвих колізій графині Валевської.

«Набагато спокійніше впасти з аероплана, ніж перекинутися на потязі» [Рот 1998:148]. А, втім, ще зручніше бути начальником станції Фальмерайєром, повз котру рухатиметься експрес... Над Йозефом Ротом, як і над згаданим протагоністом одного 3 його творів незмінно світило «сузір'я» австрійської Південної залізниці. Рот - людина шляху. Його тексти - то ще один спосіб мандрівки. Різновид, який давав змогу, синтезувати реальне та потенційне.

Романи, повісті, новели прозаїка - футурологічні, наділені здатністю збуватися щодо його подальшої долі і, водночас, вони втілення внутрішнього та зовнішнього досвіду. «Ми знали більще, ніж старі, ми були нещзасними онуками, щуо взявщи на коліна до себе своїх дідусів, розказували їм історії», напише він у «Білих містах» [Рот 1998:80]. Проте і ці межі пізнання видадуться авторові тісними. Заперечуючи Камю, котрий стверджував, що «у нас немає досвіду смерті» [Камю 1989:231], Рот назве представників своєї генерації «воскреслими мерияями», «навантаженими всією потойбічною мудрістю» [Рот 1998: 83]. «Білі міста», що не мають наскрізного сюжету, де я-оповідач виконує єдину дію - споглядання - утопія, з острівним часом, метатекст, який дозволяє комунікаціювати певні побічні метасмисли. Тут реєстр важливих для письменника проблем і відповіді на вічні питання, що «ходять вулицею» [Ніцше 1990:310].

Ліон, описаний в манері дорожніх нотаток, примітний серед інших міст своїми цінами. "Чи не найпомірніме вартує тут життя... стільки ж, як скромна платня, дешеве вино чи недільний сеанс у кінотеатрі» [Рот 1998:87]. В Авіньйоні антропоморфізм доведений до крайньої межі: «Іcyc - mo справжнісінький римський хлопчик» [Рот 1998:108]. «Марсель - то ворота світу, Марсель - поріг народів. Марсель - то Схід і Захід. Звідси відпливали у Святу Землю хрестоносиі. Цю гавань минали на иляху в Свропу казки «Тисячі й 
однієї ночі». До иього берега приставали орієнтальні мотиви» [Рот 1998:130]. У всі попередні малолюдні міста я-оповідач приходив як дзеркало, щоб якщо не помножити, то хоча б констатувати життя. У Марселі він - перехожий. Тут люди не потребують помноження $\mathrm{i}$, якщо воно й відбувається, то попри їхню волю, як у провулку Кохання [Рот 1998:134]. У Німі подибуємо пращура «Собору»: «У храмі Діани мешканці Німа влаштували заледве не контору магістрату, в «Maison Cагreе», щуо колись був храмом Юпітера, замість невеликого музею урядили Відділ запису актів громадянського стану, у здоровенному амфітеатрі-арбітраж...» [Рот 1998:120-121].

Уперше білі міста Рот побачив тридцятилітнім. Південно-французька топоніміка пов'язувалась із вивільненням душі, містичним світлом, зблиском щастя в очах. Щоправда, пізніше Схід і темнота («Моє сіре дитинство пройшло в сірих містах. Молодість мою забрали сіра та червона військові служби, казарма, шаниі, лазарет» [Рот 1998:79]) знайшли прихисток у відчуттях вигнанця.

Рот називає дитинство (а воно пройшло у Бродах на Волині, де i народився) сном, але це той сон, що справджуватиметься все його подальше життя. У своєму трактуванні зв'язку з юними роками митець ближчий до Юнга (Фрейд всю увагу звертав на раннє дитинство індивіда, Юнг - роду), «... хотів би, щэоб нові люди, наступні і прийдешні, люди всіх форм, через які ми ще йдемо і які мають пройти крізь нас, зберегли зв'язок із дитинством Свропи, зі своїм власним дитинством, або ж віднайшли б його, як я» [Рот 1998:120].

Ці пошуки дитинства (за однією 3 версій батько Рота вмер ще до народження сина від алкоголізму, за іншою - коли Йозефу виповнилось 16 років, божевільним) - трансформація пошуків батьківщини. У 1918-му із мап світу зникає василіск із короною Габсбургів на голові - Австрійська імперія, первісна батьківщина «вічних мандрівців», до яких належав і Йозеф Рот. Окрім того, він опиняється між життєвими формами двох поколінь: передта повоєнного. Поза бажанням Рота змінилися просторово-часові координати, - 
і він воліє залишитися анахронізмом у вигаданому музеї, обирає роль медіума, вперто стирає кордон між фікцією та дійсністю.

У новелі «Бюст імператора» «безпричальний» письменник записує анамнез після констатації смерті наддержави: «... стара Австро-Угорська імперія вмерла не від порожнього патосу революиіонерів, а від іронічної невіри тих, хто мав би бути стовпом віри, ї̈ підтримуючи» [Рот 1998:61]. Однак «навіть той, хто втратив свою землю, бере з собою найкращуе, щуо може дати батьківщина - тугу за нею» [Рот 1998:139].

Королівство Галичини й Володомерії - периферія імперії - імпонувало Йозефу Роту строкатістю населення, маленькими єврейськими містечками (по материнській лінії Рот - єврей). Його космополітизм надзвичайно природній, позиція продиктована кровними інтересами. Хоча у будь-якому разі: чи то розглядаючи політичну точку зору, чи естетичні уподобання - не слід забувати про міфо-комплекс, наскрізний у світовідчутті цього представника «вічних napï̈в.

3 малих років Рот «сповнений тихої злоби і жовчі, ненависті до багатіїв, але без солідарності з бідними». Небезпека охлократії підштовхне його пізніше до легітимізму, у виборі між Гітлером та Габсбургами - монархія є меншим злом. Стефан Цвейг дав мотивацію антимілітаристських поглядів письменника: «Не те, щзо його власні книги були спалені, щзо його ім'я зникло з історії літератури, не особисте образило і зачепило до самоӥ глибини його єство, а те, щзо він побачив, як перемагають на землі диявольські принциии: ненависть, насильство, брехня, щзо - як сам висловлювався - побачив торжество антихриста на землі - $і$ и̧е перетворило його життя в суцільний безвихідний відчай» [Цвейг 2003: Електронний ресурс].

В жертву антихристу в роки другої світової війни під час акції 3 «ліквідації психічно неповноцінних» принесена душевнохвора дружина Рота.

Рот переймає в експресіоністів концепцію «збожеволілого світу» який належить знищити. I лише у романах, де можна блукати виключно під парасолькою, панує сентиментальність, меланхолійна іронія і така, властива 
творцю гра. Рот - антинауковий, проте не антиінтелектуальний автор, добра освіта котрого не переходить в заангажованість. (По закінченні гуманітарної гімназії у Бродах, вивчав у Лодзі та Відні філософію і германістику. Там же, у Відні, молодий спудей слухав лекції 3 літератури, як початкуючий, але талановитий поет).

3 романів Рота можна вивести дерево життя, яке точніше було б назвати деревом кохання, що, як i мандрівки, - $\epsilon$ незмінною темою письменника. Врешті, ці речі в іпостасі можливостей переінакшення світу - споріднені. Фізичне пересування у просторі призводить до змін душевного стану. Особистість під час просторового переміщення втрачає машкару. Кохання внутрішня робота, завдяки якій стара предметність охоплюється новим мерехтливим, ряхтючим світлом. Неокочівництво і любов - шляхи подолання законсервованості і герметизму, нехай ілюзорний, нехай тимчасовий вихід в інобуття. Стиль життя та стилістика мистецтва у Рота ізоморфні.

Сюжет новели - «Квітень. Історія одного кохання» - нескладний. Вона збудована на таємниці: дівчині у вікні та незрозумілій антипатії головного героя до помічника машиніста. Розвиток дії вичерпується - i тільки тоді відкривається розгадка, перемога протагоніста прочахає присмаком поразки.

Рот-художник пильнує точності. Ми «плутаємо назви з речами», хоча «між назвою та поняттям, щуо його позначає назва, завжди буде досить вільного простору» [Рот 1998:82]. Ця прогалина те, що не увійшло від відчуття до його абстракції - слова, різниця, міра викривлення.

Філігранність у відтворенні характерів та відтінків почуття спостерігаємо в новелі «Начальник станції Фальмерайєр» (1933), яка є чи не кращим поетично-психологічним твором Рота. Жалість та обов’язок в графині Валевській переважують кохання. Достоту вони більш реальні, тривалі i богосхвальні. Дещиця нелогічності $€$ в поведінці Ані Валевської, коли довідується про приїзд чоловіка, однак ще не здогадується про його каліцтво. Хоча, врешті, і тут обов'язок. 
Адам Фальмерайєр - космополіт, як i автор. Особистим щастям, завдячуючи порушенню миру, «кожного ранку, кожного вечора Фальмерайєр благословляв війну ц̆ окупащуію» [Рот 1998:49]. Анна - патріотка: «Вона відмовилася, - правила графиня далі, - покинути свій дім. А інші втікли. Вона не втече ні від своїх селян, ані від ворога» [Рот 1998:45]. Адам силоміць вивозить графиню з України. Зважаючи на це, розв'язка не видається такою несподіваною, ієрархія цінностей Валевської не зліплена 3 Адамового ребра. «Начальник станції Фальмерайєр» - фотонегатив до «Коханця леді Чаттерлей».

Рот-автобіограф, на відміну від Рота-художника, до точності не надто схильний. У персональній біографічній розповіді він шахраює, вигадує небилиці, провокує скандал серед сучасників, для яких істина - предмет поклоніння. Рот - за професією - журналіст, хронікер старої Австрії - ігнорує факти, вперто витворює міф, де він декоративний, кайзерівсько-королівський лейтенант (хоча ніколи цього звання не удостоювався, його дворічна служба була радше репортерською); на додаток чіпляє собі хрест та інші військові нагороди.

Штукарство Рота деяких літературознавців підштовхує вбачати у його прихильностях та несприйнятті лише зміну «іронічних масок». Навіть спорядження Рота в останню найкоротшу мандрівку вилилося у бучну дискусію: як поєднати католицьку церемонію (Рот запевняв, що він - католик) iз східноєврейськими учасниками процесії, котрі йтимуть за домовиною?

Таким чином, можемо зробити висновок про те, що попри фікціоналізацію дійсності, яка властива Роту-письменнику, його художня та публіцистична проекція Першої світової війни 3 погляду антропологічного, психологічного (поведінкових ситуацій героїв) - людинознавчого у найширшому розумінні - $€$ важливим доповненням до верифікованих історичних джерел. А концепти часопростору, ідентичності (iї зміни в гендерних, регіональних, соціальних, національних та інших рамках), катастрофізму - функціонально-важливі, смислотворчі чинники у конструюванні цієї образно-художньої візіі. Сама ж назва «Велика світова 
війна» для Йозефа Рота асоціювалася не стільки 3 масштабом бойових дій, як із крахом старого свіmy - колишньої дунайської монархії.

\section{БІБЛІОГРАФІЯ}

Камю 1989 - Камю А. Миф о Сизифе. Эссе об абсурде / А. Камю // Сумерки богов. - М. : Политиздат, 1989. - С. 222-318.

Красильщиков 2013 - Красильщиков, Аркадий. Случай Стефана Цвейга. - Електронний pecypc : 5.10.2013. http://a.kras.cc/2013/10/blogpost_1185.html

Ніцше 1990 - Ницше Ф., Фрейд 3. и др. Сумерки богов / Ф. Ницше, 3. Фрейд и др. - Москва : «Политиздат», 1990. - 398 с.

Рот 1998 - Рот, Йозеф. Білі міста: Вибране / Йозеф Рот. - К. : Смолоскип, 1998. - $216 \mathrm{c}$.

Рот 1994 - Й. Рот. Из писем: [Вступительная статья, составление и перевод В. Седельника] / Рот, Й. - Вопросы литературы, 1994. - № 6. C. $174-227$.

Цвейг 2003 - Цвейг С. Йозеф Рот / Стефан Цвейг// Вестник Европы: Журнал европейской культуры. - 2003. - № 9. - Електронний ресурс : http://magazines.russ.ru/vestnik/2003/9

Roth 1984 - Roth J. Die Flucht ohne Ende. Ein Bericht / Joseph Roth // Roth J. Die Rebellion. Frühe Romane. - Berlin und Weimar : Aufbau-Verlag, 1984.S. 429-550 - Електронний pecypc: http://gutenberg.spiegel.de/buch/die-fluchtohne-ende-8647/1 